\title{
A STUDY ON LIFE INSURANCE PENETRATION IN INDIA
}

\author{
R. RADHIKA ${ }^{1} \&$ RAMESH KUMAR SATULURI ${ }^{2}$ \\ ${ }^{1}$ Research Guide, GITAM University, Rudraram Mandal, Sangareddy District, Patancheru, \\ Hyderabad, Telangana, India \\ ${ }^{2}$ Research Scholar, GITAM University, Rudraram Mandal, Sangareddy District, Patancheru, \\ Hyderabad, Telangana, India
}

ABSTRACT
With the passage of IRDA Act 1999, Insurance Industry was opened to private companies and as of now we
have 24 Life Insurance Companies in India operating with a deployed capital of $~ 36625$ crores, 20 lakh distributors and
32.5 crore in-force policies. Since 1956 we have completed $~ 60 y r s$ of operations but Life Insurance penetration is still at
$2.72 \%$ as on 2017. India remains one of the lowest penetrated economies across the globe. We see huge divergence in
penetration across states in India. Insurance density is at \$47 which is again the lowest when we compare with peer
countries and global average. With $~ 11000$ Insurance branches across the country we still struggle to reach out masses
and penetrate deeper in rural pockets.
This paper is trying to address the issue of low penetration and suggestive measures to all the stake holders to
improve Life Insurance Penetration.
KEYWORDS: Life Insurance, Penetration, Density, Premium \& Insurance Companies

Received: Dec 17, 2019; Accepted: Jan 07, 2019; Published: Jan 23, 2019; Paper Id.: IJHRMRFEB201912

\section{INTRODUCTION}

Insurance penetration is measured in terms of \% age of premium (in \$) to GDP (in \$). Assuming India's GDP is at $\$ 100$ and total collected premium in the country is $\$ 3$ then the Insurance penetration in the country is Total Collected Premium/Value of GDP*100=\$3/ $\$ 100 * 100=3 \%$

Insurance density on the other hand is measured in terms of \%age of premium(in \$) to the total population. Assuming the same example of India's total collected premium at $\$ 3$ and India's population at 100 people then the Insurance density is Total Collected Premium/Total population $=\$ 3 / 100 * 100=\$ 3$

Whereas Insurance penetration is calculated to understand the contribution of Insurance premium to the GDP, Insurance density is a measure to understand per capital premium for the country. Both the measures are utilized to comprehend the growth in the insurance sector.

The origin of insurance industry can be dated back to the 13th century, when European traders wanted to hedge the risk of theft when they travel to sell their goods across the globe. In India, while the origin of Insurance can be dated back to pre-British era the Indian Insurance movement can be evaluated from the passage of the LIC act on 1st September 1956. Since then till 2000 end LIC monopolized the entire life insurance operations in India. With the passage of IRDA act 1999, Insurance industry was opened to private insurance companies and as on December' 2018 we have 24 Life Insurance companies operating in India including LIC. It's more than 60 yrs. 
since we started our insurance operations however our Life Insurance penetration is one of the lowest. Life Insurance penetration and among the prominent countries is as follows.

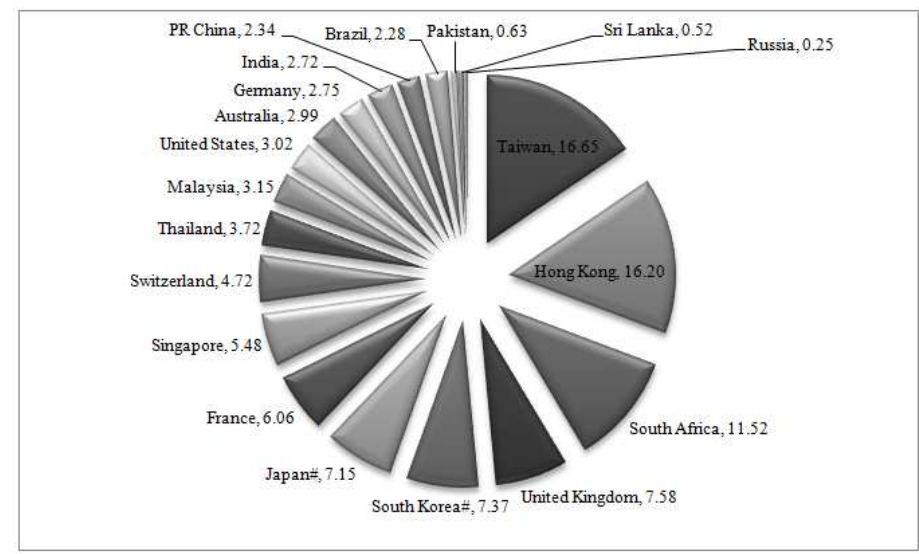

Figure 1

Table 1

\begin{tabular}{|l|c|}
\hline \multicolumn{1}{|c|}{ Country } & Penetration \\
\hline Taiwan & 16.65 \\
\hline Hong Kong & 16.20 \\
\hline South Africa & 11.52 \\
\hline United Kingdom & 7.58 \\
\hline South Korea\# & 7.37 \\
\hline Japan\# & 7.15 \\
\hline France & 6.06 \\
\hline Singapore & 5.48 \\
\hline Switzerland & 4.72 \\
\hline Thailand & 3.72 \\
\hline Malaysia & 3.15 \\
\hline United States & 3.02 \\
\hline Australia & 2.99 \\
\hline Germany & 2.75 \\
\hline India & $\mathbf{2 . 7 2}$ \\
\hline PR China & 2.34 \\
\hline Brazil & 2.28 \\
\hline Pakistan & 0.63 \\
\hline Sri Lanka & 0.52 \\
\hline Russia & 0.25 \\
\hline World & $\mathbf{3 . 4 7}$ \\
\hline
\end{tabular}

Source: Handbook of Indian Insurance Statistics 2016-17

New business premium grew steeply between 2000 and 2007 and took a dip after that. It took growth momentum from 2014 onwards. Insurance industry registered a CAGR of 15\% in the last 16years however penetration remains a cause of concern.

\section{OBJECTIVES OF THE STUDY}

- To understand the issue of Life Insurance Penetration in India

- To suggest measures in enhancing the Life Insurance Penetration in India 


\section{DESIGN/METHODOLOGY/APPROACH}

This paper is descriptive in nature which aims to study Life Insurance penetration and suggestive measures to enhance the Life Insurance penetration in India

Related review of literature is structured around the key components of Life Insurance Penetration and Life Insurance Density.

\section{LIMITATIONS}

- Limited time to study the penetration of Life Insurance Industry

- The research is limited to reviewing the literature and best practices in the Indian Life Insurance Industry

\section{LITERATURE REVIEW}

KSHETRIMAYUM SOBITA DEVI (2011) ${ }^{1}$ in her thesis titled "A STUDY OF THE IMPACT OF LIBERALIZATION ON THE INDIAN LIFE INSURANCE INDUSTRY" studied the impact of privatization and the role played by private companies in the Indian insurance industry. The author also studied the insurance penetration between 1999 and 2009 and opined that Insurance density has a direct correlation with the GDP performance.

Raja Babu (2012) ${ }^{2}$ in his thesis titled "INSURANCE SECTOR REFORMS IN INDIA" studied major reforms initiated in the Indian Insurance sector and the period of study was between 2001 and 2010. He opined that development of Insurance sector is dependent on overall economic development of the nation and Govt. of India need to take enough steps to generate employment opportunities in various sectors which in turn will promote the industry.

Insurance Times Magazine (2012) ${ }^{3}$ an Insurance magazine in its article "Life insurance penetration in India higher than global average" stated that life insurance penetration in India was higher than the world average in 2010. It further stated that the combined average is higher than Brazil and Russia and most of the other countries of Asia, including Bangladesh, Pakistan, China and Sri Lanka.

Insurance Times Magazine (2013) ${ }^{4}$ the Insurance magazine in its article "State-wise life insurance penetration and density of individual new business in India" opined that Insurance penetration is correlated with the country's GDP. With every point of increase in GDP there is a proportionate increase in insurance penetration.

Insurance Times Magazine(2018) ${ }^{5}$ an Insurance magazine in its article "India's insurance gap widens despite deeper penetration, says study" compared Insurance penetration across globe and opined that one of the key reasons for this low level of insurance is that as the number of natural catastrophes such as flooding increase, so do insurance prices. As a result, businesses, governments and households less at risk are deterred from taking out insurance.

\section{ENHANCING LIFE INSURANCE PENETRATION}

Penetration in Life Insurance Industry can be enhanced through proper coordination between various stakeholders viz. Insurance Companies, IRDAI and Government of India. Following are the suggestions for all the stakeholders. 
Table 2

\begin{tabular}{|c|c|}
\hline Suggestions & Description \\
\hline $\begin{array}{l}\text { Insurance Accounting } \\
\text { Process }\end{array}$ & $\begin{array}{l}\text { Presently Insurance Industry in India follows Non-IFRS, which are not comparable with } \\
\text { Global Standards. Non-IFRS does not permit Insurance Companies to amortize the initial } \\
\text { expenses and hence the cost is front loaded which results in losses for companies. }\end{array}$ \\
\hline Expense Regulations & $\begin{array}{l}\text { Present Expense Regulations discourage companies to go for expansion and hence } \\
\text { regulator should keep branch expansion outside the purview of overall expense } \\
\text { regulation. }\end{array}$ \\
\hline $\begin{array}{l}\text { Initiation from Govt. of } \\
\text { India }\end{array}$ & $\begin{array}{l}\text { Govt. launched schemes viz. Pradhan MantriJeevanJyotiBimaYojana (PMJJBY), } \\
\text { Pradhan Mantri Suraksha Bima Yojana (PMSBY) and Atal Pension Yojana (APY) could } \\
\text { add up only close to } \sim 13.54 \text { crore policy holders. These schemes require big push from } \\
\text { GOI. }\end{array}$ \\
\hline Branch Expansion Plan & $\begin{array}{l}\text { IRDAI should come out with a road map on branch expansion as we have only } \sim 10900 \\
\text { Life Insurance Branches across the country. The Onus to expand branch network lies } \\
\text { with Insurance companies and the regulator has not put any obligation for companies and } \\
\text { hence we do not see major expansion happening in the Industry. }\end{array}$ \\
\hline Agency Career & $\begin{array}{l}\text { Agency career has taken a beating with the reduction of commission. Agency is always } \\
\text { perceived as part time role due to meagre earnings. Agency career should be made very } \\
\text { lucrative by offering higher monetary and non-monetary benefits. }\end{array}$ \\
\hline $\begin{array}{l}\text { Insurance Awareness } \\
\text { Campaign }\end{array}$ & $\begin{array}{l}\text { Need to have structured awareness campaign using Digital Marketing and Social } \\
\text { networking sites. Insurance Companies should be mandated to conduct minimum number } \\
\text { of awareness programs in a year. }\end{array}$ \\
\hline Poor Customer Service & $\begin{array}{l}\text { Inferior customer service is one of the reasons why people don't buy insurance products. } \\
\text { We need to have stringent regulations in punishing companies which do not maintain } \\
\text { higher standards of precision in customer service. }\end{array}$ \\
\hline Product Innovation & $\begin{array}{l}\text { Insurance products lack innovation and do not offer comprehensive solution to customer. } \\
\text { We need product innovation to make them more appealing for end user. }\end{array}$ \\
\hline $\begin{array}{l}\text { New Distribution } \\
\text { Channels }\end{array}$ & $\begin{array}{l}\text { IRDAI should venture more into new distribution channels viz. SHGs, mandis, web } \\
\text { aggregators, POS and online marketing firms. }\end{array}$ \\
\hline $100 \%$ FDI & $\begin{array}{l}\text { FDI should be enhanced to } 100 \% \text { so that we have more foreign companies starting their } \\
\text { operations in India thus getting access to technical knowhow and product innovation. }\end{array}$ \\
\hline $\begin{array}{l}\text { Insurance Edu } \\
\text { Universities\& }\end{array}$ & $\begin{array}{l}\text { Insurance education should start from primary and secondary school thus creating } \\
\text { awareness among the masses. }\end{array}$ \\
\hline Surplus Distribution & $\begin{array}{l}90 \% \text { surplus is quite high considering that shareholders will take back only } 10 \% \text { and this } \\
\text { will defer their break even discouraging companies to expand further. }\end{array}$ \\
\hline Mis Selling & $\begin{array}{l}\text { IRDAI need to plan for regular Insurance awareness programs across and encourage } \\
\text { agents to get certified for specialized courses like CFP, FIII etc. also recognizing ethical } \\
\text { practices and agents with need based selling. }\end{array}$ \\
\hline $\begin{array}{l}\text { Exclusive Tax Ber } \\
\text { to LI Products }\end{array}$ & $\begin{array}{l}\text { To encourage customers invest in Life Insurance we need to have exclusive tax benefits } \\
\text { for LI products than grouping them with other investments under } 80 \mathrm{C} \text {. }\end{array}$ \\
\hline Role of LIC & $\begin{array}{l}\text { LIC as a big brother has a major role to play in enhancing penetration. We need LIC } \\
\text { setup more branches in rural areas which requires deep penetration. }\end{array}$ \\
\hline Products simplicity & $\begin{array}{l}\text { Insurance products are complex and the language used to explain the same is quite } \\
\text { complicated. We needed simplicity }\end{array}$ \\
\hline \multirow[t]{2}{*}{$\begin{array}{l}\text { Simplicity in Issuance } \\
\text { Role of IIB }\end{array}$} & $\begin{array}{l}\text { Companies need to invest in digital to automate the entire process from proposal stage to } \\
\text { issuance stage thus encouraging customers with ease of convenience. }\end{array}$ \\
\hline & $\begin{array}{l}\text { Insurance Information Bureau should start sharing data and statistics which should reveal } \\
\text { potential untapped markets to Insurance companies and the business opportunity. }\end{array}$ \\
\hline Separate MI regulations & $\begin{array}{l}\text { IRDAI has not mandated insurance companies to set up Micro Insurance offices and } \\
\text { selling MI products which surely will help the industry with deeper penetration. While } \\
\text { Regulator has come with Rural Obligation we have not seen much progress on Micro } \\
\text { Insurance Penetration. We have mere } \sim 35000 \text { MI Agents to serve } \sim 130 \text { crore population. }\end{array}$ \\
\hline Annual Target to IRDAI & $\begin{array}{l}\text { IRDAI needs to balance out between customer welfare and growth of life insurance } \\
\text { companies. Any new regulation should not obstruct the expansion plans of Life Insurance } \\
\text { Companies. }\end{array}$ \\
\hline
\end{tabular}




\section{CONCLUSIONS}

The total collected premium in Life Insurance Industry amounted to $~ 4.5$ lakh crores for the year 2017-18. The industry could achieve this figure with a mere $\sim 2.7 \%$ Life Insurance penetration with $\sim 32$ crore in-force policies. India remains the most favoured destination for Foreign Direct Investment and insurance industry is no exception to this.

India has nearly 46 crore population who are internet savvy and this is driving the entire behaviour and hence we see a huge spike on digital transactions. Gen $\mathrm{Z}$ is slowly going to replace Millennials across the globe and India is no exception to this. Gen $\mathrm{Z}$ is the one who has seen only digital world and wallet payments and this group is going to influence the entire Digital Scenario. India, which has a 1.3 billion population will see 472 million Gen $\mathrm{Z}$ populations by next year. Insurance Companies need to advertise more in engaging Gen $\mathrm{Z}$ customers and understand their buying and behavioural patterns.

The insurance industry needs to invest heavily in analytics, digital, Artificial Intelligence and Robotics. With entire population moving to smart phone usage, we have an enormous opportunity to reach out every individual in both rural and urban by investing in technology thus enhancing insurance penetration above global average.

\section{REFERENCES}

1. IIB Bulletin Report 2017-18

2. IIB Fact Book 2016-17

3. IRDA Annual Report 2016-17

4. IAIS Report 2017

5. Handbook on Indian Insurance Statistics 2010-11, IRDA.

6. Sastry, D V S (2011): Life insurance penetration in India, Journal of Social and Economic Policy, Vol. 8, No. 2, 207-215.

7. Asaduzzaman, M., Hamid, M. K., \& Afrin, SAMINA. (2014). Corporate Environmental Reporting (CER) practices: empirical evidence from selected non-financial companies in Bangladesh. International Journal of Business and general Management, 3(1), 1-8.

8. Sinha, R K, Nizamuddin M M and Alam, I (2012): An Investigation of insurance penetration and density of India by geography, 
